\title{
S100A8, S100A9 and S100A12 Expression in myeloid cells from whole blood from patients with common lung diseases
}

\author{
Mann Ying Lim ${ }^{1,2}$, David Simar ${ }^{1}$, SharronChow ${ }^{1}$, Kenneth Hsu ${ }^{1}$, Craig R. Lewis ${ }^{3}$, Carolyn L. Geczy ${ }^{1}$ and Paul S. Thomas ${ }^{1,2 *}$ \\ ${ }^{1}$ Inflammation and Infection Research Centre, School of Medical Sciences, University of New South Wales, NSW, Australia \\ ${ }^{2}$ Department of Respiratory Medicine, Prince of Wales Hospital, Randwick, Sydney, NSW, Australia \\ ${ }^{3}$ Department of Medical Oncology, Prince of Wales Hospital, Randwick, Sydney, NSW, Australia
}

\begin{abstract}
Introduction or Hypothesis: The myeloid-associated calgranulins, S100A8, S100A9 and S100A12 are associated with inflammatory lung diseases and S100A9 is proposed as a possible prognostic marker in non-small cell lung cancer (NSCLC). We proposed that expression patterns of the calgranulins may discriminate between healthy persons and those with lung disease and/or cancer.

Methods: We compared S100A8, S100A9 and S100A12 expression in CD14+CD11b+ monocytes and CD14- CD11b+ granulocytes in whole blood from patients with lung diseases (NSCLC, chronic obstructive pulmonary disease (COPD)), with their expression in the corresponding controls (smokers and non-smokers) using flow cytometry. S100A8, S100A9 and S100A12 levels serum were measured by enzyme-linked immunosorbent assays (ELISAs); nitrate/nitrite (NOx) concentrations in serum and exhaled breath condensate (EBC) were quantitated using a modified fluorometric assay based on the Griess method.

Results: S100A9 was more abundant than S100A8 or S100A12 in granulocytes, but S100A9 levels in monocytes and granulocytes were not significantly different. S100A8 levels in monocytes were significantly lower than in granulocytes in all groups except in patients with NSCLC. We identified a subset of granulocytes, differentiated by high/low expression of CD11b. Except for S100A12, there was significantly more S100 expression in CD11-high populations; CD11b-low granulocytes from smokers or patients with lung cancer contained significantly less S100A12 than CD11b-high cells. Serum S100A8, S100A9 and S100A12 concentrations were similar in all groups, but serum from patients with NSCLC contained significantly higher NOx levels than samples from non-smokers $(9.8 \pm 1.5$ vs $6.9 \pm 0.78 \mu \mathrm{M}$ respectively, $\mathrm{p}=0.0019$ ) while no differences were found in $\mathrm{EBC}$.
\end{abstract}

Conclusions: Calgranulin levels in granulocytes and monocytes from patients with lung diseases did not discriminate between groups although uncharacteristically, S100A8 levels in granulocytes and monocytes from patients with NSCLC were similar. Serum NOx was increased in NSCLC and may be associated with MDSC, but roles for the $\mathrm{S} 100$ proteins in terms of pathogenesis, or distinguishing between the various pulmonary diseases need further assessment.

\section{Introduction}

The S100 proteins known as calgranulins, S100A8, S100A9 and S100A12, are constitutively expressed in neutrophils and monocytes, and are generally associated with inflammatory processes [1,2]. In lung diseases, S100A8/S100A9 have been suggested as a potential surrogate marker of disease severity in human tuberculosis and proposed to mediate chronic airway inflammation and remodelling in asthma [3.4]. There are relatively few studies investigating levels of the individual proteins, although S100A8 is elevated in sputum from groups of patients with bronchiectasis and cystic fibrosis [5]. S100A12 is also significantly higher than S100A8/S100A9 in lung lavage fluid from patients with the acute respiratory distress syndrome (ARDS) [6]. Sputum from patients with eosinophilic asthma contains elevated S100A12 concentrations and S100A12 is possibly a marker of sepsisrelated lung injury, and a prognostic marker of idiopathic pulmonary fibrosis [7-10]. In lung-associated cancers, S100A8 is elevated in lavage fluid from patients with adenocarcinoma and expression appears related to cancer progression [11]. Murine models implicate S100A8 in the establishment of a pre-metastatic niche in the lung while S100A9 over-expression in lesions from patients with non-small cell lung cancer (NSCLC) is associated with a poor prognosis $[12,13]$. On the other hand, low expression of S100A8 and S100A12 in tissue sections from patients with oropharyngeal squamous cell carcinoma was associated with decreased overall survival [14]. We recently identified novel antiinflammatory properties of S100A8. It induces interleukin-10 (IL-10) in airway lining epithelial cells and, like glucocorticosteroids, completely suppressed leukocyte recruitment in acute lung injury (ALI) [15]. Moreover, S100A8 is a potent scavenger of NO, ROS and hypochlorous acid $(\mathrm{HOCl})$ and these properties contribute to its anti-inflammatory effects in ALI, and acute asthma in mice [16-18]. These seemingly paradoxical properties of S100A8 may be dependent on the cell types affected within the microenvironment, its concentration and its antioxidant properties that promote post-translational modifications that may act as switches that regulate function $[16,19]$.

Correspondence to: Professor Paul Thomas, Departments of Respiratory Medicine, Prince of Wales Hospital, Randwick, Sydney NSW 2031, Australia, Tel: +61 293824620, Fax: +61 293824627; E-mail: paul.thomas@unsw.edu.au

Key words: S100A8, S100A9, S100A12, NOx, MDSC

Received: December 04, 2016; Accepted: February 01, 2017; Published: February 10, 2017 
Myeloid-derived suppressor cells (MDSC) are a heterogeneous population of immunoregulatory myeloid cells that moderate ongoing inflammation and consist of myeloid progenitors, macrophage precursors, granulocytes, and dendritic cells (DC) and can be found at tumour sites [20]. Human MDSC express the common myeloid markers CD33 and CD11b, but not markers of more mature myeloid or lymphoid cells [21]. MDSC dampen innate and adaptive immunity by suppressing natural killer (NK) cell cytotoxicity and CD4 ${ }^{+}$Th1 helper $\mathrm{T}$ cell or $\mathrm{CD} 8^{+}$cytotoxic $\mathrm{T}$ lymphocyte activation, partially by depleting $\mathrm{L}$-arginine and cysteine and increasing toxic nitric oxide (NO) levels via regulation of inducible nitric oxide synthase (iNOS), arginase 1 (ARG1) and generation of reactive oxygen species (ROS) [22-24].

S100A9 overexpression promoted MDSC accumulation in peripheral blood and inhibited macrophage and dendritic cell differentiation [25]. Although reportedly associated with immunological abnormalities in cancer, MDSC also modulate immunosuppression in chronic inflammatory conditions, including asthma-related airway inflammation [26]. Interestingly, passive transfer of tumour-derived MDSC restored the Type-2 helper T (Th2) cell balance to normal in murine asthma and suppressed recruitment of inflammatory cells into lungs of antigen-challenged animals, prolonged corneal allograft survival and reduced graft-versus-host disease, indicating important roles for these cells in normal homeostasis [27-29].

S100A9 is proposed as a marker of MDSC in the circulation of patients with certain cancers including NSCLC, where over-expression in monocytes is associated with a poor prognosis and reduced responses to chemotherapy [21,30]. Feng et al. found that peripheral blood mononuclear cells (PBMC) from these patients expressed a higher frequency of S100A9-positive cells, intracellular levels were elevated, and S100A8 was also increased compared to normal donors. S100A9 levels also correlated with the suppressive capacity of $\mathrm{CD} 11 \mathrm{~b}^{+} \mathrm{CD} 14^{+}$ MDSCs in NSCLC and reduced responses to chemotherapy [31]. Supporting these observations, immunohistochemistry indicated increased S100A8 and S100A9 expression in NSCLC tissue compared to adjacent and peripheral lung tissue [32]. More recently, following the discovery of monocytic CD $14^{+} \mathrm{IL}-4 \mathrm{Ra}^{+}$and $\mathrm{CD} 11 \mathrm{~b}^{+} \mathrm{CD} 14^{+} \mathrm{HLA}-\mathrm{DR}^{\mathrm{lo} / \mathrm{neg}}$ MDSCs in the circulation of patients with colon cancer and melanoma respectively, a population of monocytic $\mathrm{CD} 11 \mathrm{~b}^{+} \mathrm{CD} 14^{+} \mathrm{CD} 15^{\text {lo/ }}$ ${ }^{\text {neg } C D 33}{ }^{+} \mathrm{S} 100 \mathrm{~A}^{+}{ }^{+}$cells were linked to NSCLC. S100A8, S100A9 and

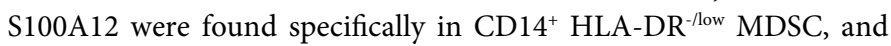
increased numbers of $\mathrm{CD} 14^{+}$cells containing S100A9 were reported in blood from patients with colon cancer [21,31,33-35].

Here we assessed S100A8, S100A9 and S100A12 levels in $\mathrm{CD} 11 \mathrm{~b}^{+} \mathrm{CD} 14^{+}$monocytes and $\mathrm{CD} 11 \mathrm{~b}^{+} \mathrm{CD} 14$ granulocytes in whole blood and serum from patients with NSCLC, COPD, and smokers and non-smokers without these diseases to test the hypotheses that the calgranulins would differ between diseases and cell type. Intensity of S100A9 expression was higher than that of S100A8 and S100A12. S100A8 expression in granulocytes was higher than in monocytes, whereas S100A9 and S100A12 levels were generally similar. However, in contrast to the other groups, granulocytes and monocytes from patients with NSCLC contained similar levels of S100A8 whereas serum levels of S100A8, S100A9 and S100A12 did not differ between clinical groups. We quantitated nitrate/nitrite (NOx) in serum and exhaled breath condensate (EBC) as NO can promote neoplastic growth through DNA damage, by modifying protein structures during oxidative stress, and MDSC reduce $\mathrm{T}$ cell activation via NO-related pathways $[39,40]$. Serum NOx concentrations were significantly higher in the NSCLC group compared to non-smokers.

\section{Materials and methods}

\section{Subjects}

Ethics approval was granted by the South Eastern Sydney Area Health Service Research Ethics Committee (SESAHS HREC12/119); all participants completed informed, written consent. The study comprised four clinical groups: subjects with newly-diagnosed untreated NSCLC, stable COPD, current smokers and non-smokers (Table 1). NSCLC was diagnosed by cytology or histopathology; COPD was diagnosed clinically together with appropriate response to bronchodilators using spirometry [41]. Smokers included subjects who regularly smoked one or more cigarettes per day [42]. Demographic and medical details were collected by questionnaire and participants with other respiratory conditions, current or recent infections, or pregnancy, excluded.

\section{Flow cytometry}

Whole Blood Leukocyte Staining: Expression of intracellular S100A8, S100A9 and S100A12 was measured using a FACSCalibur cytometer (BD Biosciences, California, USA). Reactivities of rabbit anti-S100A8, anti-S100A9 and S100A12 immunoglobulins G (IgGs) prepared in-house are described by McCormick et al., and Goyette et al. $[43,44]$. Anti-S100A8 and anti-S100A12 IgGs did not cross-react with other calgranulins; anti-S100A9 reacted with the S100A8/S100A9 complex but not with S100A8.

Fresh venous blood was collected in heparin-coated Vacutainer tubes (BD Biosciences Pharmingen, California, USA) and $100 \mu \mathrm{l}$ incubated in $2 \mathrm{ml} \mathrm{NH4Cl-containing} \mathrm{lysis} \mathrm{solution} \mathrm{for} 10$ minutes at room temperature (RT) in the dark. Samples were centrifuged at 300x g for 5 minutes at RT then lysed erythrocytes in supernates removed. Cells were washed thrice with $2 \mathrm{ml} 1 \%$ bovine serum albumin (BSA, SigmaAldrich, NSW, Australia) in phosphate-buffered saline (PBS, called wash buffer), resuspended in $200 \mu$ l wash buffer, fixed by addition of 50 $\mu \mathrm{l} 10 \%$ paraformaldehyde (PFA) in PBS and incubated at $4^{\circ} \mathrm{C}$ overnight. After washing twice with $10 \mathrm{ml}$ of wash buffer, cells were resuspended to a final volume of $200 \mu$ then kepton ice for 5 minutes. After adding $1.8 \mathrm{ml} 100 \%$ methanol kept at $-80^{\circ} \mathrm{C}$, cells were immediately transferred to $-20^{\circ} \mathrm{C}$ for 30 minutes. After three washes, cells resuspended in 100 $\mu \mathrm{l}$ wash buffer were stained with $10 \mu \mathrm{l}$ phycoerythrin-conjugated antiCD14 (clone number M5E2, BD Biosciences Pharmingen, California, USA), $1 \mu \mathrm{g}$ fluoresce in isothiocyanate-conjugated mouse anti-human CD11b (clone number M1/70, BioLegend, California, USA), $1 \mu \mathrm{g}$ of either biotin-conjugated anti-human S100A8, S100A9 or S100A12 IgG or biotin-conjugated rabbit IgG control (Molecular Innovations, Michigan, USA) and incubated for 20 minutes at RT in the dark in a final volume of $117 \mu \mathrm{l}$. After two washes, $5 \mu \mathrm{l}$ of allophyocyaninconjugated streptavidin (BD Biosciences Pharmingen, California, USA) were added and cells incubated for 20 minutes at RT in the dark, washed twice, then fixed with $300 \mu \mathrm{l} 1 \%$ PFA in PBS and kept at $4^{\circ} \mathrm{C}$ until analysis. All staining procedures were performed within two hours of blood collection to minimise signal loss.

\section{Flow cytometric analysis}

Data were acquired on a FACS Calibur (BD Biosciences, California, USA) and compensations were applied using single stained tubes. Forward and side scatter of lymphocyte, monocyte, and granulocyte populations allowed gating based on size and granularity (Figure 1A). Granulocytes comprised $\mathrm{CD} 11 \mathrm{~b}^{+} \mathrm{CD} 14$ gated populations (Figure 1B). Among these, subpopulations of granulocytes expressing high $\left(\mathrm{CD} 11 \mathrm{~b}^{\mathrm{hi}}\right)$ or low $\left(\mathrm{CD} 11 \mathrm{~b}^{\mathrm{lo}}\right)$ expression of $\mathrm{CD} 11 \mathrm{~b}$ were identified and 
Table 1. Subject demographics. Age, smoking pack-years, Mean FEV1\% predicted and Mean FEV1/FVC $\%$ are presented as means \pm SD

\begin{tabular}{|c|c|c|c|c|c|}
\hline & Non-smoker & Smoker & COPD & NSCLC & p-values \\
\hline $\mathbf{n}$ & 14 & 5 & 12 & 12 & NA \\
\hline Median age (range) & $55(21-85)$ & $43(36-49)$ & $67(45-82)$ & $68(59-80)$ & 0.003 \\
\hline Female/ Male & $6 / 8$ & $2 / 3$ & $7 / 5$ & $4 / 8$ & NA \\
\hline Median pack years (range) & 0 & $24.00(6.50-36.25)$ & $30.50(0-76.00)$ & $54.25(0-122.50)$ & $<0.0001$ \\
\hline Smoking (current/ former/ never) & $0 / 0 / 14$ & $5 / 0 / 0$ & $8 / 4 / 0$ & $3 / 7 / 2$ & NA \\
\hline Mean FEV $1 \%$ predicted & $101.90 \pm 14.71$ & $95.14 \pm 17.99$ & $59.75 \pm 15.30$ & $63.95 \pm 9.64$ & $<0.0001$ \\
\hline Mean FEV $_{1} /$ FVC \% & $81.63 \pm 7.17$ & $74.61 \pm 14.44$ & $64.42 \pm 9.66$ & $59.68 \pm 10.86$ & 0.0002 \\
\hline Inhaled corticosteroid (yes/ no) & $0 / 14$ & $1 / 4$ & $7 / 5$ & $3 / 9$ & NA \\
\hline Adenocarcinoma & & \multirow{4}{*}{ NA } & & $5^{*}$ & NA \\
\hline Large cell carcinoma & & & & $1 *$ & NA \\
\hline Squamous cell carcinoma & & & & $4^{*}$ & NA \\
\hline Stage I/ II/ III/ IV & & & & $1 / 0 / 3 / 3 *$ & NA \\
\hline
\end{tabular}

*=Some data missing; NA= not applicable.

A

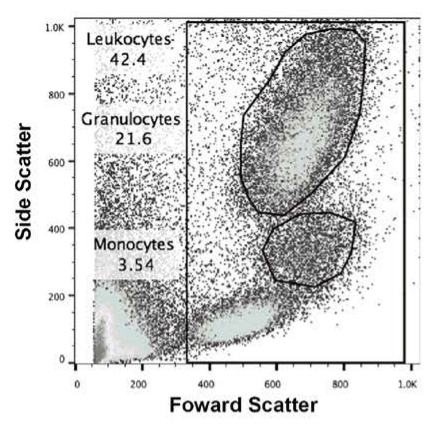

E

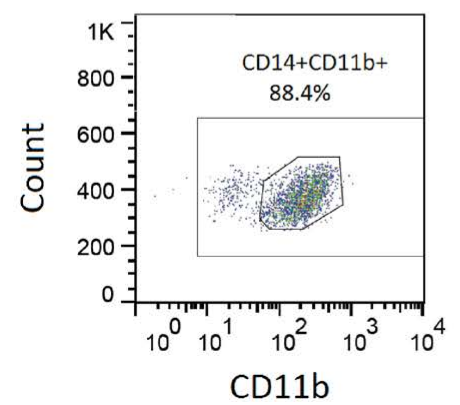

B

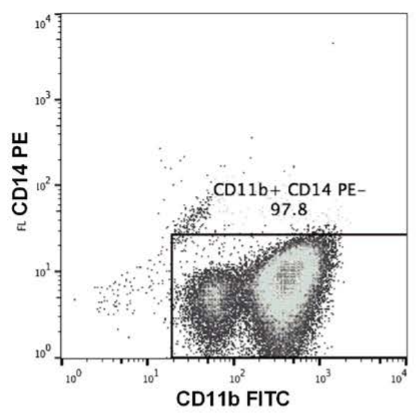

$\mathbf{F}$

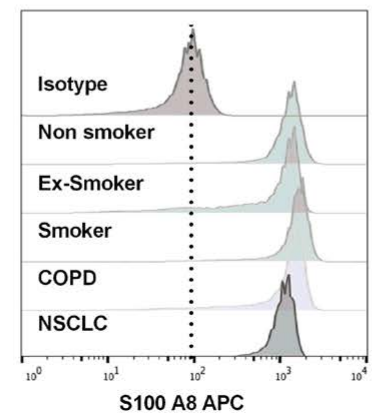

C

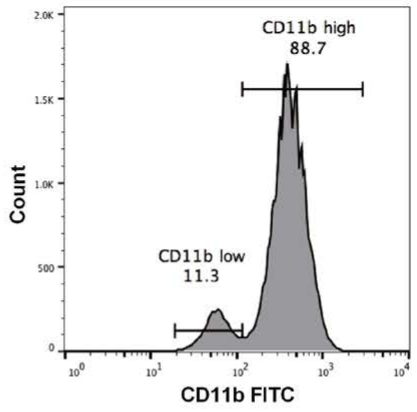

G

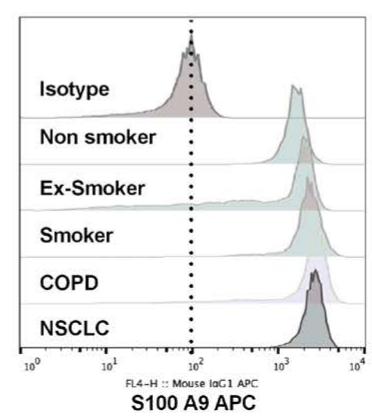

D

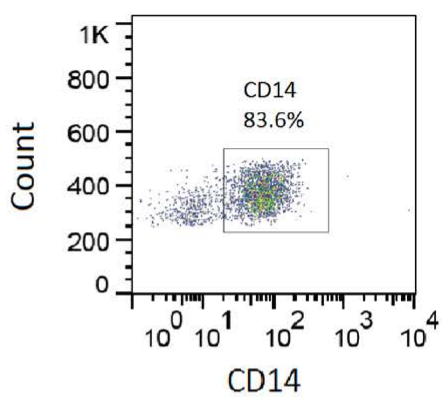

H

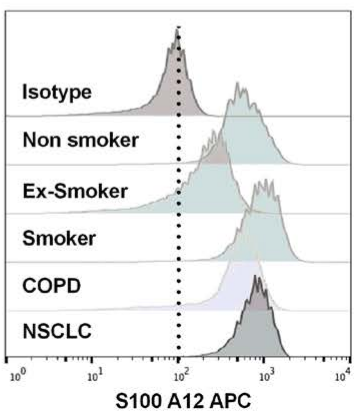

Figure 1. Gating strategy of flow cytometry results. Blood cells from a normal donor were used as an example. Granulocytes and monocytes were gated based on size and granularity (A). Granulocytes constituted $21.6 \%$ and monocytes $3.54 \%$ of the leukocytes gated (A). Two populations CD11b CD14 granulocyteswereidentified, one with high CD11b,the other with low CD11b expression (B). Among the CD11 b ${ }^{+} \mathrm{CD} 14$ granulocytes, the majority expressed high levels ofCD11b (88.7\%) and $11.3 \%$ were CD11b low (C).

gated accordingly (Figure 1C). For monocytes, cells were first gated for for CD14 (Figure 1D). Among the CD14 ${ }^{+}$monocytes, those that also expressed CD11b were considered positive (Figure 1E); Levels of calgranulin expression were measured as median fluorescence intensity (MFI), and the MFI in calgranulin-positive leukocytes was normalised using the MFI from isotype controls (Figure $1 \mathrm{~F}-\mathrm{H}$ ). There was little variability present in the MFI for the isotype controls between groups. A minimum of 10,000 events was recorded and data analysed using FlowJo (Tree Star, Oregon, USA).

Since many studies report results in PBMC or neutrophils separated from whole blood, we compared S100 levels (MFI) in leukocytes separated by conventional density gradient methods with those obtained using whole blood staining, and found similar results in both (data not shown).

\section{S100A8, S100A9 and S100A12 ELISAs}

To prepare serum, blood collected in Vacutainers (BD Diagnostics) was allowed to clot for 30 minutes in a vertical position at RT then centrifuged at $1000 \mathrm{x}$ g for 10 minutes at RT. Serum aliquots $(120 \mu \mathrm{l})$ separated from the clot by a gel separator were aliquoted into $1.5 \mathrm{ml}$ Lobind Eppendorf tubes (Sigma-Aldrich, Sydney, Australia) and stored at $-80^{\circ} \mathrm{C}$.

Calgranulins in sera (diluted 1:4 v/v in PBS) and EBC were quantified by sandwich ELISAs developed in-house [45]. A 96-well MaxiSorp microplate (Nunc, Denmark) was coated with $50 \mu \mathrm{l} /$ well coating buffer $(0.05 \mathrm{M}$ sodium carbonate, $\mathrm{pH} 9.6)$ containing $4 \mu \mathrm{g} / \mathrm{ml}$ capture antibody (rabbit anti-human S100A8, S100A9 or S100A12 IgG), left at RT overnight, then wells washed three times with $300 \mu \mathrm{l}$ $0.05 \%$ Tween 20 in PBS, blocked with $200 \mu$ l 1\% skim-milk powder 
in PBS at RT for one hour, then wells washed as above. After adding $100 \mu$ recombinant S100A8, S100A9 or S100A12 standards (3.9-250 $\mathrm{ng} / \mathrm{ml} \mathrm{PBS}$ ) prepared as described, or samples, to duplicate wells, plates were incubated for two hours at RT then washed as above [46]. Detection antibody, $100 \mu \mathrm{l}(4 \mu \mathrm{g} / \mathrm{ml}$ biotinylated rabbit antihuman S100A8, S100A9 or S100A12 IgG) was added, plates incubated for two hours at RT, washed, then $100 \mu$ streptavidin-horseradish peroxidase (HRP) (R\&D Systems, USA) added to each well and plates incubated in the dark at RT for 30 minutes. After three washes, 100 $\mu \mathrm{l}$ 3,3', 5,5'-tetramethylbenzidine (TMB, Life Technologies, Victoria, Australia) was added, plates incubated for 20 minutes in the dark at RT then the reaction stopped with $50 \mu$ sulphuric acid (1M) and $\mathrm{A}_{450 \mathrm{~nm}}$ immediately read on a microplate reader (SpectraMAX, USA).

The limits of detection were $15.6 \mathrm{ng} / \mathrm{ml}, 1.95 \mathrm{ng} / \mathrm{ml}$ and $1.9 \mathrm{ng} /$ $\mathrm{ml}$ for S100A8, S100A9 and S100A12 respectively; mean intra-assay coefficients of variation were $7.4 \pm 7.3 \%, 4.7 \pm 4.7 \%$ and $2.9 \pm 2.7 \%$ respectively. Concentrations of calgranulins in samples were estimated by interpolation from the standard curve.

\section{Exhaled breath condensate (EBC) preparation}

After oral lavage with water, subjects breathed tidally for 15-20 minutes through a unidirectional valve into a non-siliconised glass condenser with a saliva trap cooled to $4^{\circ} \mathrm{C}$ in ice, using a validated method [47]. Aliquots of EBC $(120 \mu \mathrm{l})$ were immediately pipetted into $1.5 \mathrm{ml}$ LoBind Eppendorf tubes, de-aerated by flushing with high purity argon (BOC, New South Wales, Australia) at a flow rate of $0.4 \mathrm{~L} / \mathrm{min}$ for 30 seconds then stored at $-80^{\circ} \mathrm{C}$ until analysis.

\section{Nitrate/nitrite (NOx) measurement}

Total NOx concentrations were measured using a modified fluorometric assay based on the Griess method [48]. Standard solutions $(0-60 \mu \mathrm{M})$ were diluted from a stock solution of $1 \mathrm{mM}$ sodium nitrate using distilled water. In a 96-well plate, $50 \mu$ duplicate standard solutions or subject samples were mixed with nicotinamide adenine dinucleotide phosphate, flavin adenine dinucleotide and nitrate reductase (Sigma-Aldrich, Australia) to final concentrations of $50 \mu \mathrm{M}, 5 \mu \mathrm{M}$ or $50 \mathrm{IU} / \mathrm{L}$ respectively, then incubated at $37^{\circ} \mathrm{C}$ for 1 hour; 2, 3-diaminonaphthalene (DAN $(0.05 \mathrm{mg} / \mathrm{ml}), 10 \mu \mathrm{l}$ in $0.62 \mathrm{M}$ $\mathrm{HCl}$ added and plates incubated for 10 minutes in the dark. Reactions were terminated with $10 \mu \mathrm{l} 2.8 \mathrm{mM} \mathrm{NaOH}$ then reactivity read using a Cytofluor 4000 plate reader (Applied Biosystems, Victoria, Australia), excitation $360 / 40 \mathrm{~nm}$, emission $395 / 25 \mathrm{~nm}$ and gain of 50. The limit of detection was $1.25 \mu \mathrm{M}$; mean intra-assay coefficient of variation $6.5 \pm$ $5.5 \%$; nitrate concentrations were estimated by interpolation from the standard curve.

\section{Statistical tests}

Statistical analyses were performed using SPSS Statistics version 21 (IBM, New York, USA) and GraphPad Prism version 6 (GraphPad Software, California, USA). The significant probability level was set at $\mathrm{p}<0.05$ and data presented as mean \pm SD. The normality of the distributions was tested by the D'Agostino \& Pearson omnibus normality test. Differences between groups were tested using Kruskal-Wallis or Mann-Whitney tests followed by Dunn's multiple comparison test.

\section{Results}

\section{Subject demographics}

A total of 43 patients were included in this study and the demographics are summarised in table 1 . Smokers were younger than COPD and NSCLC groups as lung disease was an exclusion criterion. As expected, those with COPD and NSCLC had smoked significantly more cigarettes than other groups. Not all subjects were able to provide sufficient EBC or blood for analysis.

\section{A8, A9 and A12 expression in whole blood monocytes and granulocytes}

Flow cytometry analyses of S100A8, S100A9 or S100A12 expression in monocytes and granulocytes in whole blood samples were performed using samples from 37 individuals (12 non-smokers, 5 smokers, 9 with COPD and 6 with NSCLC) using gating strategies shown in figure 1. Figure $1 \mathrm{C}$ shows a typical plot with separation of $\mathrm{CD} 11 \mathrm{~b}^{+} \mathrm{CD} 14$ granulocytes; two populations with distinct differences in brightness of anti-CD11b reactivity (CD11 $\mathrm{b}^{+}$high or low) were separated; the $\mathrm{CD} 11 \mathrm{~b}^{\text {lo }}$ population comprised $11.3 \%$ of the total. S100 expression in these cells was measured as MFI in the various populations.

We also tested the differences between age and expression of S100A8, S100A9 and S100A12. Non-smoker subjects were divided into $<45$ years old and $>45$ years old and tested for levels of calgranulins. There was no association between age and levels of calgranulins expressed $(p=0.57,0.29,0.15$ for S100A8, S100A9 and S100A12 in granulocytes; $\mathrm{p}=0.81,0.81,0.11$ for S100A8, S100A9 and S100A12 in monocytes respectively).

Figure 2 shows of reactivity of anti-S100A8, S100A9 and S100A12 antibodies in leukocytes from each clinical group. S100A8 levels in monocytes were significantly lower (approximately half) than in granulocytes from non-smokers $(\mathrm{p}=0.01)$. Significant differences were also observed in granulocytes from smokers $(\mathrm{p}=0.03)$ and patients with COPD ( $\mathrm{p}=0.04$ ) whereas there was no significant difference in S100A8 levels in granulocytes compared to monocytes from patients with lung cancer (Figure 2B-D). S100A9 levels in granulocytes from all clinical groups were 1.8-fold, and in monocytes 2.7-fold higher than S100A8 (Figure 2). However, S100A9 levels tended to be lower in granulocytes from patients with COPD and NSCLC compared to those from nonsmokers (Figure 2A,2C-D). Only monocytes from smokers expressed significantly less S100A12 than granulocytes $(\mathrm{P}=0.03)$ (Figure $2 \mathrm{~B}$ ).

The relative abundance of S100A8, S100A9 and S100A12 in granulocytes and monocytes from all clinical groups was compared. Among the granulocytes and monocytes, there were no significant differences in the expression levels of S100A8, s100A9 and S100A12 between various clinical groups $(\mathrm{p}=0.61$ and $\mathrm{p}=0.57$ for granulocytes and monocytes respectively). In granulocytes from non-smokers, S100A12 was significantly less abundant than S100A8 $(\mathrm{p}=0.02)$ or S100A9 $(\mathrm{p}<0.01)$ whereas no significant differences in amounts of S100A8 and S100A9 were found between these cells (Figure 3A). In contrast, S100A9 levels in monocytes from this group were significantly higher than those of S100A8 (2.8-fold; $\mathrm{p}=0.04)$ or S100A12 (8.4-fold; $\mathrm{p}<0.01)$. Differences in S100A9 and S100A12 expression levels in granulocytes from smokers $(\mathrm{p}<0.01)$, or those with COPD $(\mathrm{p}<0.01)$ or NSCLC $(\mathrm{p}=0.01)$ remained significantly different (Figure $3 \mathrm{~B}-\mathrm{D})$. The significant differences seen in S100A8 and S100A12 levels in granulocytes could not be replicated in smoking $(\mathrm{p}=0.41)$, COPD $(\mathrm{p}=0.048)$ and NSCLC $(\mathrm{p}=0.06)$ groups, although there was a strong trend. These comparisons were perhaps underpowered to detect a true difference with multiple comparisons, but were significant if unadjusted unpaired t-tests were used (estimated minimum sample size, 1-beta 0.8 , alpha $5 \%, n=16, n=6$ and $n=6$, respectively). Only monocytes from non-smokers and patients with COPD had significantly more S100A9 

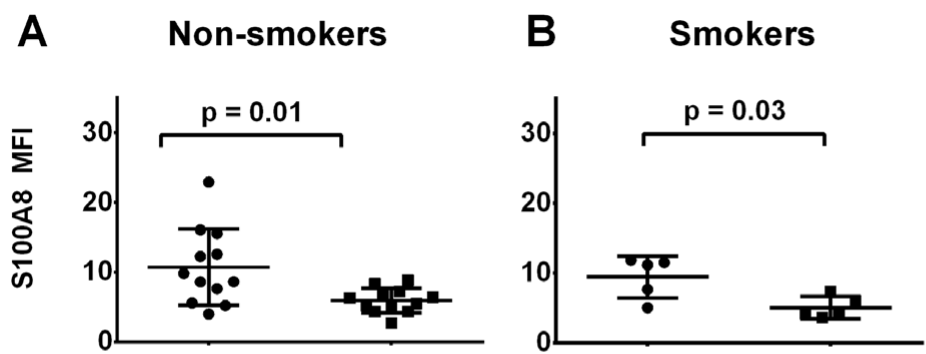

C COPD

D Lung Cancer
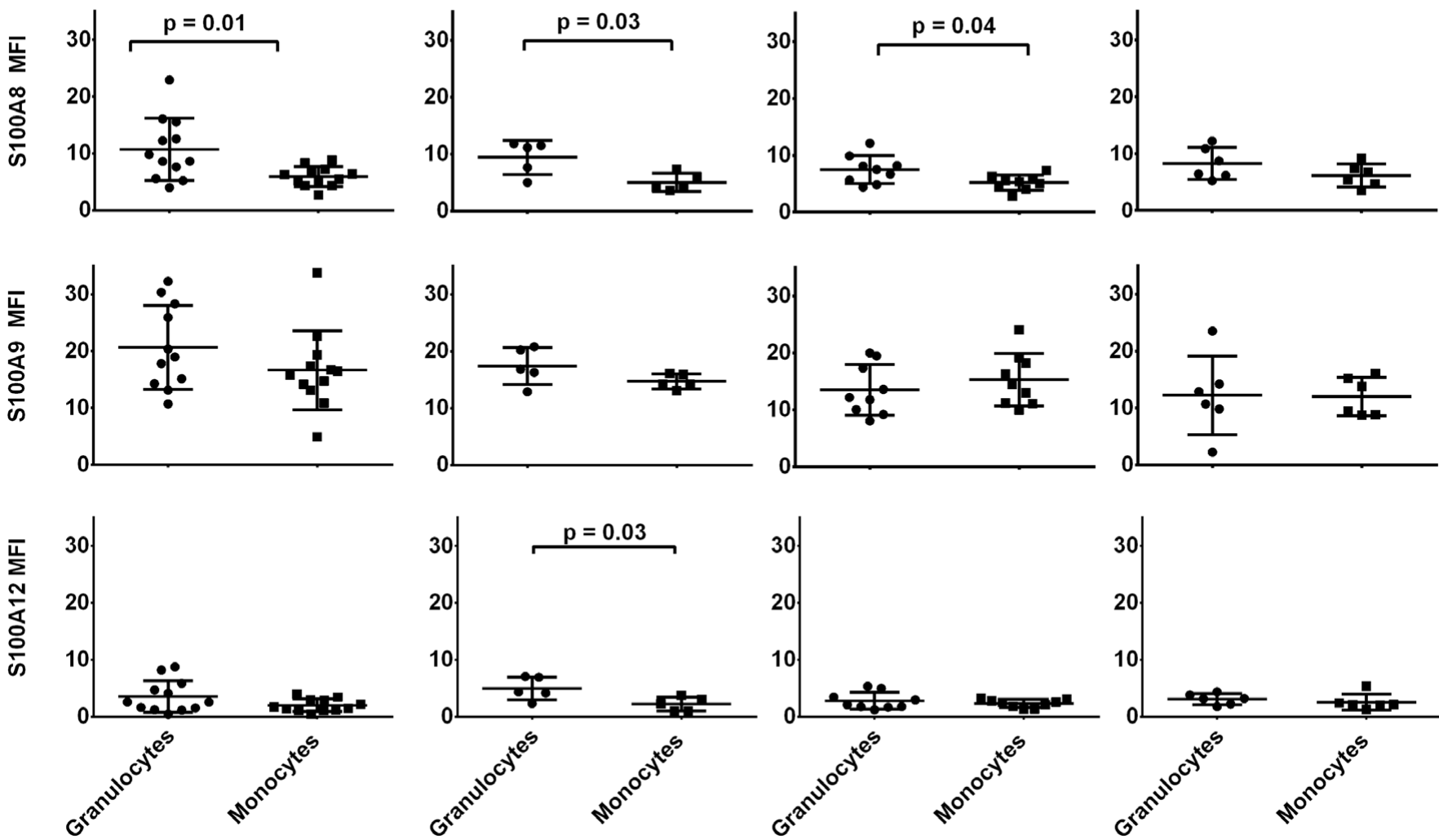

Figure 2. S100 protein expression in monocytes was lower than in granulocytes. In granulocytes from healthy donors, the MFI of anti-S100A12 reactivity was significantly less than seen for anti-S100A8 or S100A9 ( $\mathrm{p}=0.02$ and $\mathrm{p}<0.01$ respectively). No significant differences were seen between $\mathrm{S} 100 \mathrm{~A} 8$ and $\mathrm{S} 100 \mathrm{~A} 12$ levels in granulocytes from the clinical groups, although S100A9 levels were significantly higher. Monocytes from these groups reflected similar differences. Levels of S100A9 were significantly higher than S100A8 ( $\mathrm{p}=0.01$ ) in monocytes from non-smokers and those with COPD. *MFI value are normalised to isotype control.
A
Non-smokers
B Smokers
C COPD
D Lung Cancer
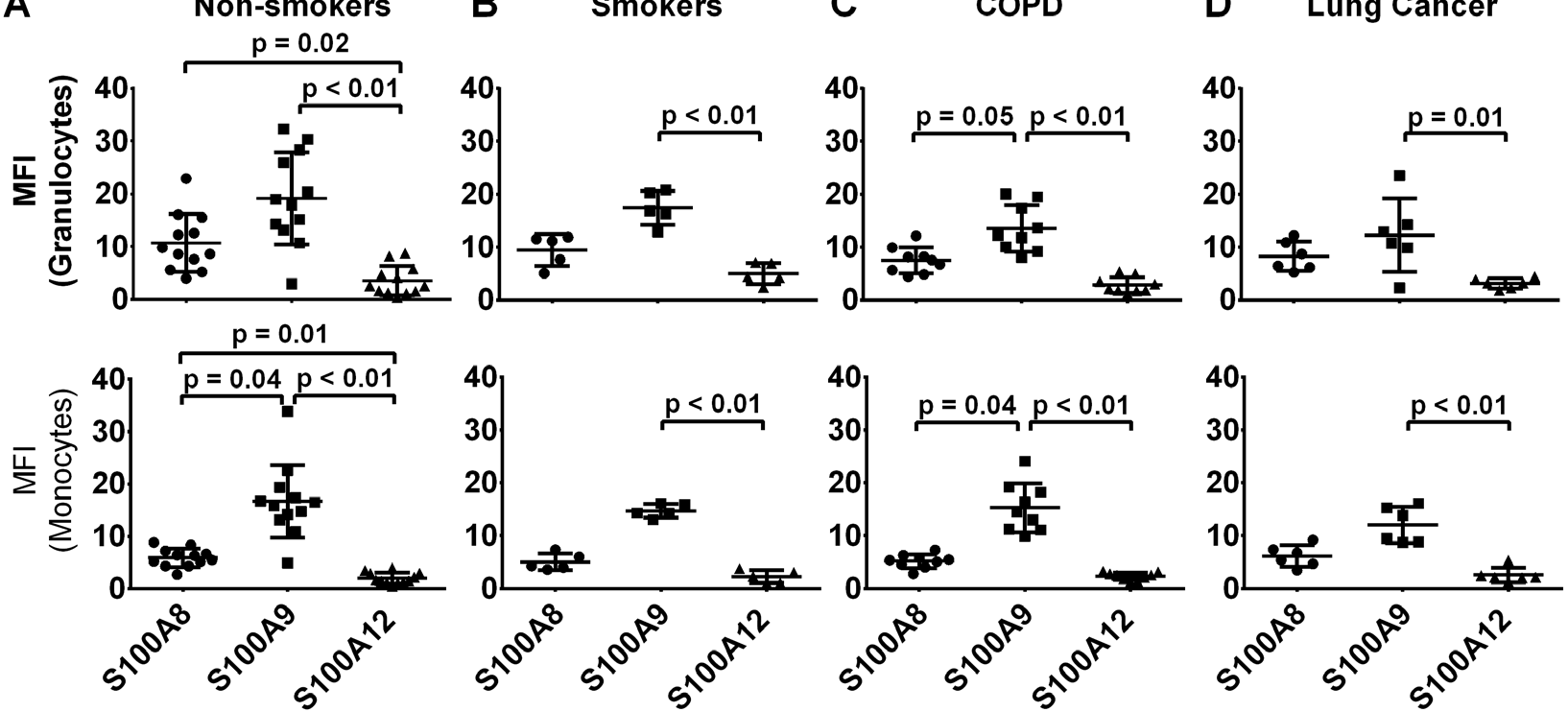

Figure 3. Levels of S100A8 were significantly higher in granulocytes than monocytes in all clinical groups except for those with lung cancer group ( $\mathrm{p}=0.01$, $\mathrm{p}=0.03$ and $\mathrm{p}=0.04$ respectively). In contrast, S100A9 and A12 levels in granulocytes and monocytes were similar in all clinical groups except for smokers where the intensity of anti- S100A12 reactivity in granulocytes was significantly higher than reactivity in monocytes $(\mathrm{p}=0.03)$. *MFI value are normalised to isotype control. 
than S100A8 ( $\mathrm{p}=0.04$ for both), even though a trend was also observed in smokers $(\mathrm{p}=0.19)$ and NSCLC $(\mathrm{p}=0.19)$ group, likely underpowered (minimum sample size for unadjusted comparisons both $\mathrm{n}=5$ for both). In contrast, differences in levels of S100A9 and S100A12 remained statistically significant in smokers and those with COPD or NSCLC $(\mathrm{p}<0.01$ for the 3 groups, Figure $3 \mathrm{~A}-\mathrm{D})$.

We next assessed whether potential differences in S100 expression levels in the $\mathrm{CD} 11 \mathrm{~b}^{+} \mathrm{CD} 14$ neutrophil subpopulations may identify a particular clinical group. Among the $\mathrm{CD} 11 \mathrm{~b}^{\text {hi }}$ and $\mathrm{CD} 11 \mathrm{~b}^{\text {lo }}$ subpopulations, there were no significant differences in the expression levels of S100A8, S100A9 and S100A12 when compared between the various clinical groups $(\mathrm{p}=0.84, \mathrm{p}=0.67$ respectively). Figure $4 \mathrm{~A}$ shows that among the individual clinical groups, the CD11b $\mathrm{b}^{\text {hi }}$ subpopulation contained similar $\mathrm{S} 100$ levels to the total granulocyte population (Figure $3 \mathrm{~A}$ ), and significant differences in S100A9 and S100A12 reactivity in this subpopulation were seen in all groups (Figure 4B-D). In contrast, significantly higher amounts of S100A9 compared to S100A12, were only found in the $\mathrm{CD} 11 \mathrm{~b}^{\text {lo }}$ subpopulation from non-smokers or patients with COPD (Figure 4A, C, $\mathrm{p}=0.01, \mathrm{p}<0.01$ ). S100A8 levels were similar in these cells from all clinical groups

$\mathrm{CD}_{1} 1 \mathrm{~b}^{\mathrm{hi}}$ granulocytes contained significantly more S100A8 (2.6-fold in cells from non-smokers, $\mathrm{p}<0.01 ; 2.5$-fold in cells from patients with NSCLC, $\mathrm{p}=0.02$ ) and S100A9 (3.2-fold in cells from non-smokers, $\mathrm{p}<0.01 ; 2.6$-fold in cells from patients with NSCLC, $\mathrm{p}=0.04$ ) than the $\mathrm{CD} 11 \mathrm{~b}^{\text {lo }}$ subpopulation from all subjects (Figure 5). In contrast, amounts of S100A12 were similar in both subpopulations of granulocytes from non-smokers and those with COPD, but lower in $\mathrm{CD} 11 \mathrm{~b}^{\mathrm{lo}}$ granulocytes from smokers or those with lung cancer.

\section{S100A8, S100A9 and S100A12 in serum}

A8, A9 and A12 were detected in serum from the 38 subjects (12 non-smokers, 5 ex-smokers, 5 smokers, 9 with COPD and 7 with NSCLC) but no statistical differences in levels were found between the groups (overall mean serum levels of S100A8, S100A9 and S100A12 were $78.2,55.6$ and $73.0 \mathrm{ng} / \mathrm{ml}$ respectively, $\mathrm{p}=0.48,0.53$, and 0.42 for A8, A9 and A12, Kruskal-Wallis, Figure 6A-C).

\section{NOx in Serum and EBC}

NOx was measured in 27 serum samples (8 non-smokers, 5 smokers, 7 with COPD and 7 with NSCLC). Serum from subjects with NSCLC contained significantly more NOx $(9.8 \pm 1.5 \mu \mathrm{M})$ than serum from non-smokers $(6.9 \pm 0.8 \mu \mathrm{M}, \mathrm{p}=0.0003$, Mann Whitney test, $)$ but not more than in samples from smokers or subjects with COPD (Figure 6D).

NOx was detected in the $32 \mathrm{EBC}$ samples tested (11 non-smokers, 4 smokers, 10 with COPD and 7 subjects with NSCLC). No significant differences were found between the groups ( $\mathrm{p}=0.91$, one-way ANOVA, Figure 6E).

\section{Discussion}

S100A8 and S100A9 are abundantly expressed in blood neutrophils and monocytes; in neutrophils, the S100A8/A9 complex is estimated to comprise $\sim 45 \%$ of total cytosolic proteins, and in monocytes, around $1 \%$ [49]. S100A12 expression is less, and mainly in granulocytes, with low levels in monocytes, that may represent a later stage of maturation [50]. Our earlier studies found some 4-fold more constitutive S100A9 mRNA than S100A8 mRNA in human neutrophils; expression of both genes in monocytes was approximately 20 -fold less. Both cell types contained substantially less S100A12 mRNA [51]. The calgranulins are not expressed in lymphocytes [52-54]. These proteins are also expressed in monocytic and granulocytic MDSC, although characterisation of the three calgranulins in these subpopulations has been scant. One study using flow cytometry identified the proteins in CD14 ${ }^{+} \mathrm{HLA}-\mathrm{DR}^{(-)}$ low) cells and the authors suggested that $\mathrm{CD} 14^{+} \mathrm{S} 100 \mathrm{~A} 9^{+}$MDSC from peripheral blood differentiated between healthy donors and those with colon cancer, on the basis of concentrations of S100A9 [21]. Based on this, we compared calgranulin expression in CD11b CD14 ${ }^{+}$and CD11b
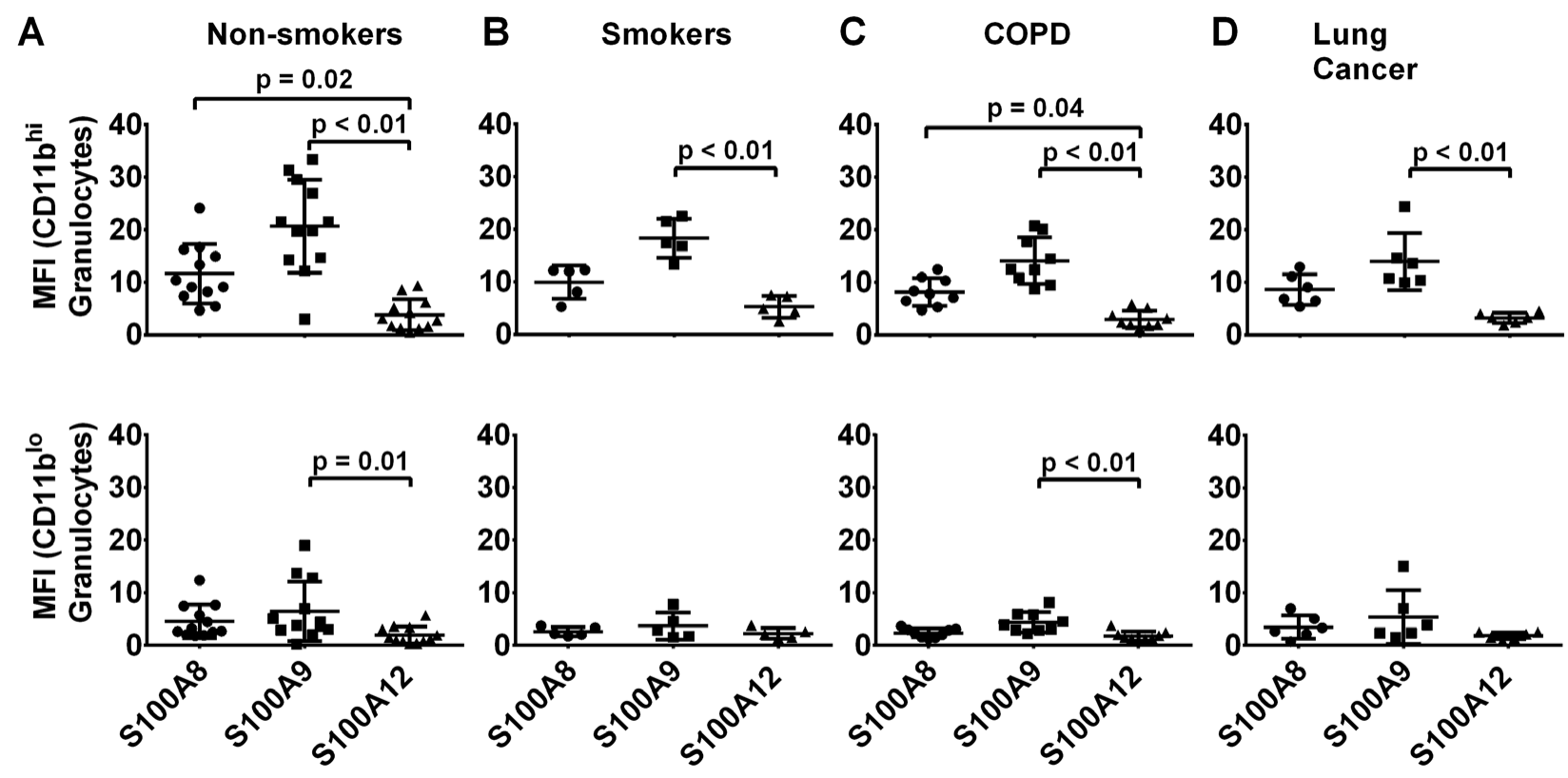

Figure 4. Comparisons of S100A8, S100A9 and S100A12 levels in $\mathrm{CD} 11 \mathrm{~b}^{\mathrm{hi}} \mathrm{CD} 14^{-}$and $\mathrm{CD} 11 \mathrm{~b}^{\mathrm{lo}} \mathrm{CD} 14$ granulocytes from all clinical groups. CD11 $\mathrm{b}^{\mathrm{hi}} \mathrm{CD} 14^{-}$granulocytes expressed substantially more S100A8 and S100A9 than the CD11b ${ }^{\text {lo }}$ CD14- subpopulation. S100A12 levels in granulocytes were substantially less than levels of S100A8 or S100A9. * MFI value are normalised to isotype control. 


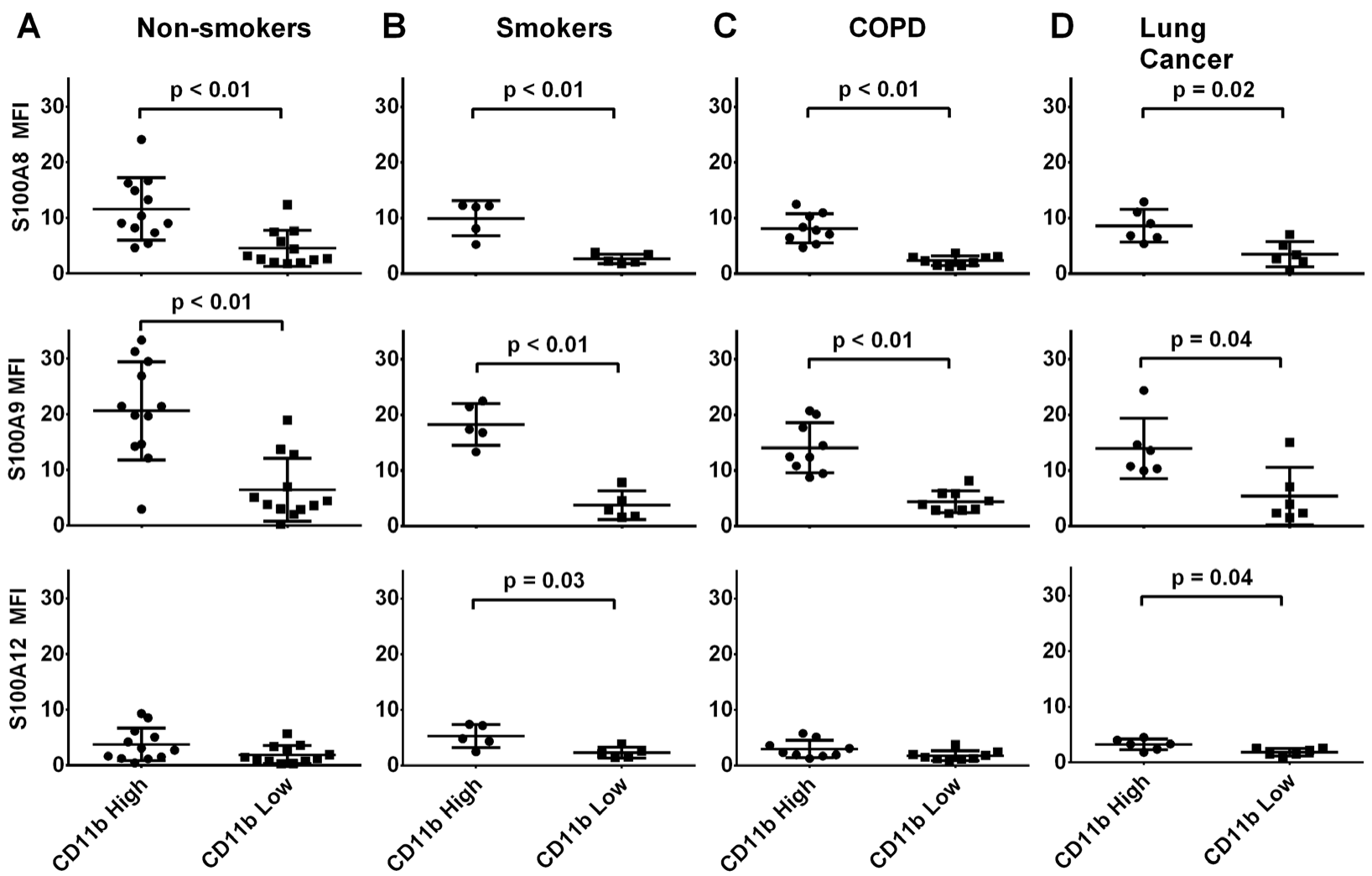

Figure 5. Among the granulocyte subpopulations, MFI of S100A 8 was significantly higher inCD $11 \mathrm{~b}^{\text {hi }} \mathrm{CD} 14^{\mathrm{c}}$ compared toCD11b ${ }^{\text {lo }} \mathrm{CD} 14^{-}$granulocytes from all clinical groups ( $<0.01$, $\mathrm{p}<0.01, \mathrm{p}<0.03$ and $\mathrm{p}=0.02$ respectively). Differences in $\mathrm{S} 100 \mathrm{~A} 9$ expresion were similar $(\mathrm{p}<0.01$ in all groups except for lung cancer where $\mathrm{p}=0.04)$. However no significant differences in intensities of anti-S100A12 reactivity were obvious inCD11 $\mathrm{b}^{\text {hi }} \mathrm{CD} 14^{-}$granulocytes from non-smokers or patients with COPD compared to levels in $\mathrm{CD} 11 \mathrm{~b}^{\mathrm{lo}} \mathrm{CD} 14{ }^{-}$granulocytes $(\mathrm{p}=0.03$ and $\mathrm{p}=0.04$ respectively). $*$ MFI value are normalised to isotype control.
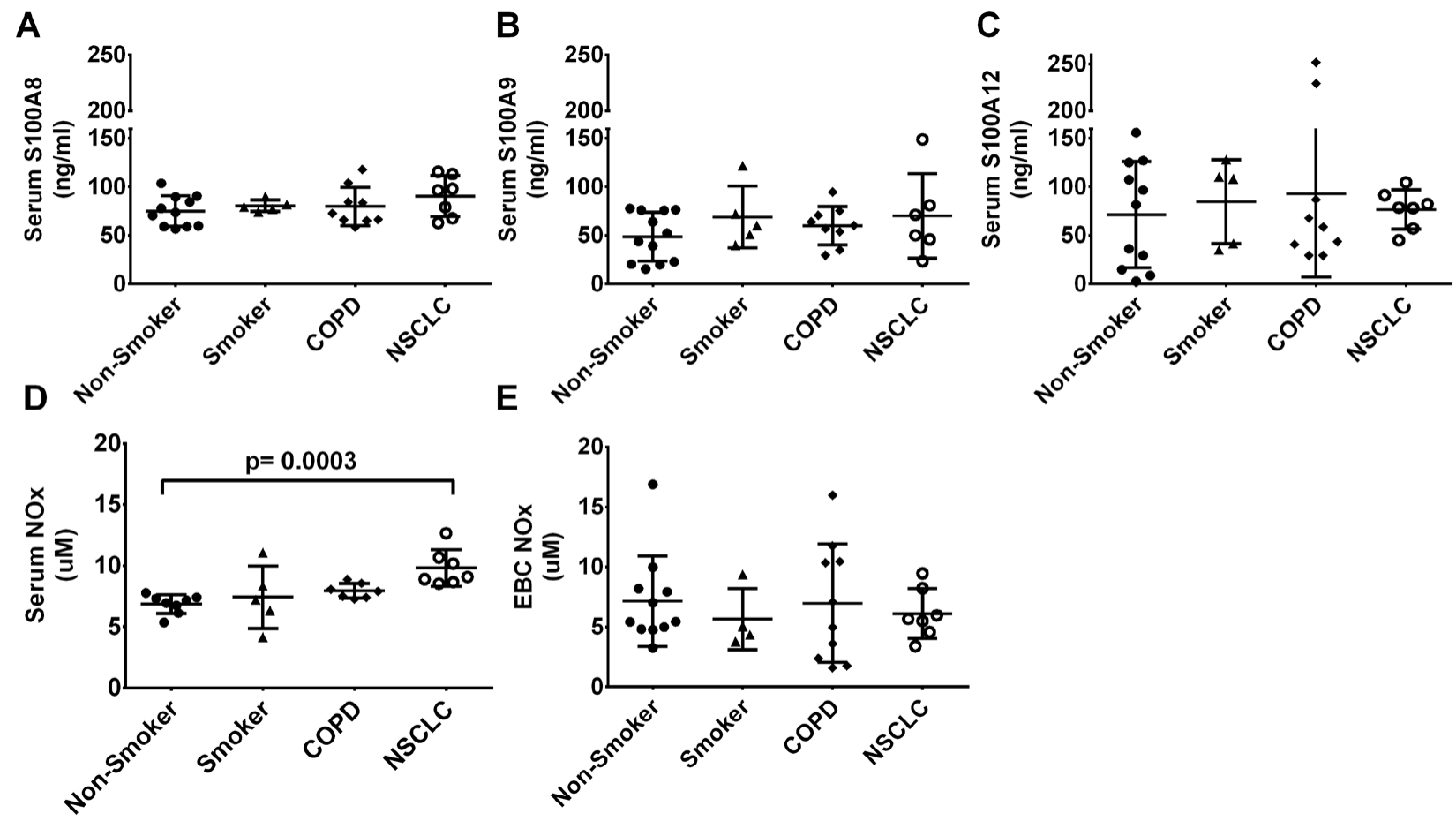

Figure 6. Serum levels of S100A8 (A), S100A9 (B) and S100A12 (C) did not differ significantly between the six subject groups. Serum nitrite/nitrate (NOx) (D) was significantly higher in the lung cancer group compared to the never-smoker group ( $\mathrm{p}=0.0019$, Kruskal-Wallis test) but the same trend was not observed in the EBC NOx (E). 
CD14 monocyte and granulocyte populations in healthy non-smokers, smokers and patients with COPD or NSCLC.

We used whole blood flow cytometry to confirm the high expression of S100A8 and S100A9 in granulocytes from non-smokers, and lower expression in monocytes (Figure 2A). Monocytes from smokers and patients with COPD contained significantly less S100A8 than granulocytes. In marked contrast to the significant differences seen in these groups, granulocytes and monocytes from patients with NSCLC contained similar amounts of S100A8 (Figure 2D). Unexpectedly, and in contrast to earlier reports we found no significant differences in S100A9 levels in granulocytes and monocytes between any clinical group and NSCLC [50]. S100A9 expression had a tendency to be lower in granulocytes from those with respiratory diseases, compared to controls. As expected, S100A12 expression was low in both cell types and similar amounts were found in each, although the S100A12expressing monocytes from smokers had a lower MFI than S100A12 ${ }^{+}$ granulocytes. Emerging evidence indicates protective rather than pro-inflammatory roles for S100A8 in the lung. S100A8 and S100A9 scavenge hypohalous acid oxidants in human asthma and intranasal treatment with S100A8 suppresses asthma and acute lung injury in murine models $[15,17,18]$. S100A8 also reduces mast cell activation and signalling that is redox-dependent [17]. Asthmatic inflammation is also reduced in transgenic mice expressing human S100A12, indicating immunosuppressive properties [55].

Human MDSC are a heterogenous group of cells with variable phenotypes and immunosuppressive features [56,57]. Earlier studies reported increased numbers of $\mathrm{CD} 11 \mathrm{~b}^{+} \mathrm{CD} 14^{+} \mathrm{S} 100 \mathrm{~A} 9^{+}$and $\mathrm{CD} 11 \mathrm{~b}^{+} \mathrm{CD} 14^{+} \mathrm{S} 100 \mathrm{~A} 8^{+}$monocytes in blood from patients with NSCLC, which was not confirmed [31]. Our observations are supported by a recent report showing that the percentage of $\mathrm{S} 100 \mathrm{~A} 9^{+} \mathrm{CD} 14^{+}$cells, and MFI of S100A9 reactivity in whole blood leukocytes was almost identical between NSCLC and healthy controls [58]. In that study, more than $80 \%$ of $\mathrm{CD} 14^{+}$cell expressed S100A9 in both groups. In addition, no differences in expression of CD14 HLA-DR CD $33^{+} \mathrm{CD} 11 \mathrm{~b}^{+} \mathrm{MDSC}$ from patients with COPD compared to smokers or non-smokers were reported [59]. Until now, S100A12 expression levels have not been compared in these cell populations from patients with lung disorders but together, our results indicate that $S 100$ expression levels did not define particular monocyte or granulocyte subpopulations from any cohort tested. Thus, their potential as markers in NSCLC and inflammatory respiratory diseases appears limited. However, comparisons of $\mathrm{S} 100 \mathrm{~A} 8^{+} \mathrm{CD} 11 \mathrm{~b}^{+} \mathrm{CD} 14^{+}$and $\mathrm{S} 100 \mathrm{~A} 8^{+} \mathrm{CD} 11 \mathrm{~b}^{+} \mathrm{CD} 14$ expressing cells may be useful, as S100A8-expressing granulocytes were statistically higher than monocytes from all groups, except for those from patients with NSCLC. It is also feasible that if additional surfaces markers (for example, CD33, HLA-DR, CD15, IL-4R) had been included, we may have detected additional differences between the groups. In this study, we analysed monocytes expression of the S100 protein levels and additional markers would better reflect the identification of MDSC.

Interestingly, we identified two subpopulations of granulocytes, based on expression of the surface integrin CD11b. Leukocyte expression of this protein increases upon activation, and higher levels on cells from patients with COPD are reported [60]. The CD11b population have only occasionally been mentioned previously [61]. Percentages of cells expressing S100A8 and S100A9 were much higher than for S100A12 in the CD14CD11b ${ }^{\text {hi }}$ population. Overall, CD14$\mathrm{CD}_{11 b^{\text {lo }}}$ granulocytes contained markedly less S100A8 and S100A9 whereas numbers of S100A12-expressing cells from non-smokers or patients with COPD were similar in CD14 CD11b ${ }^{\text {hi }}$ cells. Recent evidence points to neutrophil subsets with diverse roles that regulate inflammation, some of which impact on neutrophil transmigration [62]. $\mathrm{CD} 11 \mathrm{~b}^{\text {lo }}$ neutrophils are less adhesive to endothelial cells than CD11 bi cells and populations with these phenotypes can vary depending on treatment with glucocorticoid therapy [61]. Despite this, we found that expression on granulocytes of each subset was similar in all groups tested even though some smokers, patients with COPD or NSCLC, were on inhaled corticosteroids (Table 1). Interestingly, S100A9-deficient neutrophils have reduced responsiveness to chemoattractants and the significantly lower levels seen in CD11 b ${ }^{\text {lo }}$ neutrophils may indicate a subpopulation with functionally distinct migratory properties (Figure 5) [63]. It would be interesting to perform detailed analysis of CD14 $\mathrm{CD} 11 \mathrm{~b}^{\mathrm{lo}} \mathrm{S} 100 \mathrm{~A} 8^{\mathrm{lo}} \mathrm{S} 100 \mathrm{~A} 9^{\text {lo }}$ granulocyte subpopulations from whole blood preparations that had undergone minimal activation.

Leukocytes secrete S100A8, S100A9 andS100A12 and changes in serum concentrations are considered markers of inflammation in a number of clinical conditions. In this study, no differences in serum levels of these proteins was found between the groups, even though S100 levels in granulocytes tended to be lower in patients with COPD and NSCLC. Furthermore, some patients in our study were using inhaled corticosteroids and this drug enhances calgranulin expression in human monocytes in vitro but no evidence of such an effect was seen on circulating levels of the S100s, either in leukocytes or in serum [64]. Sampling from the site of disease, as reported for patients with asthma and COPD may more accurately reflect changes $[7,65]$. In addition, samples were taken from patients with stable disease, not during exacerbations.

Serum from patients with NSCLC had higher significantly NOx levels than non-smokers, confirming reports of elevated serum nitrated proteins in subjects with lung cancer, and suggesting a role for NOmediated stress in this disease [66]. In contrast, total NOx levels in EBC did not differ between groups. Elevated nitrite, but decreased nitrate in EBC of patients with lung cancer has been described but here we compared total nitrite concentrations that could mask changes in nitrate to nitrite ratios [66]. Although the source of NO in patients with NSCLC is unclear, and could include several cell types within the lung, circulating MDSC from patients with NSCLC also have increased NO production [66-69]. The role of NOx in MDSC warrants further investigation.

The limitations are the relatively small subject numbers in each group, and the high inter-individual variability of S100 protein expression, possibly accounted for by factors that may affect S100 protein expression not yet identified, e.g. gender, age, co-morbid medical conditions and medicaments. Another limitation is that eosinophils which are not separated during the gating process are likely to be included in the granulocyte fraction and their effect on the data is unclear.

\section{Conclusions}

We did not confirm studies suggesting that the S100s in monocytes may represent predictive factors in NSCLC. Nonetheless these quantitative comparisons of these individual proteins in CD14 CD $11 b^{\text {hi }}$ granulocytes and define a novel $\mathrm{CD} 14 \mathrm{CD} 11 \mathrm{~b}^{\text {loo }} \mathrm{S} 100 \mathrm{~A} 8^{\text {lo }} \mathrm{S} 100 \mathrm{~A} 9^{\text {lo }}$ subpopulation. Comparison of S100A8 expression in granulocytes and monocytes from patients with NSCLC indicated similar levels in each, where as in the non-NSCLC groups, granulocyte levels were significantly greater. Coupled with the significant increases in NOx concentrations found in serum from these patients, we suggest that 
further studies with larger patient cohorts is warranted to determine links between these MDSCs, the S100 proteins, NO pathways and T-cell activation.

\section{All sources of support}

National Health and Medical Research Council, grant\#APP1027189

\section{References}

1. Ghavami S, Chitayat S, Hashemi M, Eshraghi M, Chazin WJ, et al. (2009) S100A8/ A9: a Janus-faced molecule in cancer therapy and tumorgenesis. Eur J Pharmacol 625: 73-83. [Crossref]

2. Manolakis AC, Kapsoritakis AN, Tiaka EK, Potamianos SP (2011) Calprotectin, calgranulin $\mathrm{C}$, and other members of the $\mathrm{s} 100$ protein family in inflammatory bowel disease. Dig Dis Sci 56: 1601-1611. [Crossref]

3. Gopal R, Monin L, Torres D, Slight S, Mehra S, et al. (2013) S100A8/A9 proteins mediate neutrophilic inflammation and lung pathology during tuberculosis. $\mathrm{Am}$ Respir Critic Care Med 188: 1137-1146.

4. Halayko AJ, Ghavami S (2009) S100A8/A9: a mediator of severe asthma pathogenesis and morbidity? Can J Physiol Pharmacol 87: 743-755. [Crossref]

5. Gray RD, MacGregor G, Noble D, Imrie M, Dewar M, et al. (2008) Sputum proteomics in inflammatory and suppurative respiratory diseases. Am J Respir Crit Care Med 178: 444-452. [Crossref]

6. Lorenz E, Muhlebach MS, Tessier PA, Alexis NE, Duncan Hite R, et al. (2008) Different expression ratio of S100A8/A9 and S100A12 in acute and chronic lung diseases. Respir Med 102: 567-573. [Crossref]

7. Yang Z, Yan WX, Cai H, Tedla N, Armishaw C, et al. (2007) S100A12 provokes mast cell activation: A potential amplification pathway in asthma and innate immunity. $J$ Allergy Clin Immunol 119: 106-114. [Crossref]

8. Kikkawa T, Sato N, Kojika M, Takahashi G, Aoki K, et al. (2010) Significance of measuring S100A12 and sRAGE in the serum of sepsis patients with postoperative acute lung injury. Dig Surg 27: 307-312. [Crossref]

9. Takahashi G, Hoshikawa K, Matsumoto N, Shozushima T, Onodera C, et al. (2011) Changes in serum S100A12 and sRAGE associated with improvement of the PaO 2/ FiO 2 ratio following PMX-DHP therapy for postoperative septic shock. Eur Surg Res 47: 135-140. [Crossref]

10. Herazo-Maya JD, Imre Noth, Steven R. Duncan, SungHwan Kim, Shwu-Fan Ma, et al. (2013) Peripheral blood mononuclear cell gene expression profiles predict poor outcome in idiopathic pulmonary fibrosis. Sci Transl Med 5. [Crossref]

11. Almatroodi SA, McDonald CF, Collins AL, Darby IA, Pouniotis DS (2015) Quantitative proteomics of bronchoalveolar lavage fluid in lung adenocarcinoma. Cancer Genomics Proteomics 12: 39-48. [Crossref]

12. Hiratsuka S, Watanabe A, Aburatani H, Maru Y (2006) Tumour-mediated upregulation of chemoattractants and recruitment of myeloid cells predetermines lung metastasis. Nat Cell Biol 8: 1369-1375. [Crossref]

13. Kawai H, Minamiya Y, Takahashi N (2011) Prognostic impact of S100A9 overexpression in non-small cell lung cancer. Tumour Biol 32: 641-646. [Crossref]

14. Funk S, Mark R, Bayo P, Flechtenmacher C, Grabe N, et al. (2015) High S100A8 and S100A12 protein expression is a favorable prognostic factor for survival of oropharyngeal squamous cell carcinoma. Int J Cancer 136: 2037-2046. [Crossref]

15. Hiroshima Y, Hsu K, Tedla N, Chung YM, Chow S, et al. (2014) S100A8 induces IL-10 and protects against acute lung injury. J Immunol 192: 2800-2811. [Crossref]

16. Lim SY, Raftery MJ, Goyette J, Hsu K, Geczy CL (2009) Oxidative modifications of S100 proteins: functional regulation by redox. J Leukoc Biol 86: 577-587. [Crossref]

17. Zhao J, Endoh I, Hsu K, Tedla N, Endoh Y, et al. (2011) S100A8 modulates mast cell function and suppresses eosinophil migration in acute asthma. Antioxid Redox Signal 14: 1589-1600. [Crossref]

18. Gomes LH, Raftery MJ, Yan WX, Goyette JD, Thomas PS, et al. (2013) S100A8 and S100A9-oxidant scavengers in inflammation. Free Radic Biol Med 58: 170-186. [Crossref]

19. Goyette J, CL Geczy (2011) Inflammation-associated S100 proteins: New mechanisms that regulate function. Amino Acids 41: 821-842. [Crossref]

20. Serafini, P, Borrello I, Bronte V (2006) Myeloid suppressor cells in cancer: Recruitment, phenotype, properties, and mechanisms of immune suppression. Sem Cancer Biol 16:
53-65. [Crossref]

21. Zhao F, Hoechst B, Duffy A, Gamrekelashvili J, Fioravanti S, et al. (2012) S100A9 a new marker for monocytic human myeloid-derived suppressor cells. Immunology 136 : 176-183. [Crossref]

22. Hanahan D, Weinberg RA (2011) Hallmarks of cancer: the next generation. Cell 144: 646-674. [Crossref]

23. Rodriguez PC, Quiceno DG, Zabaleta J, Ortiz B, Zea AH, et al. (2004) Arginase production in the tumor microenvironment by mature myeloid cells inhibits T-cell receptor expression and antigen-specific T-cell responses. Cancer Res 64: 5839-5849. [Crossref]

24. Srivastava MK, Sinha P, Clements VK, Rodriguez P, Ostrand-Rosenberg S (2010) Myeloid-derived suppressor cells inhibit T-cell activation by depleting cystine and cysteine. Cancer Res 70: 68-77. [Crossref]

25. Cheng P, Corzo CA, Luetteke N, Yu B, Nagaraj S, et al. (2008) Inhibition of dendritic cell differentiation and accumulation of myeloid-derived suppressor cells in cancer is regulated by S100A9 protein. J Exp Med 205: 2235-2249. [Crossref]

26. Zhang YL, Luan B, Wang XF, Qiao JY, Song L, et al. (2013) Peripheral blood MDSCs, IL-10 and IL-12 in children with asthma and their importance in asthma development. PLoS One 8: e63775. [Crossref]

27. Song C, Yuan Y, Wang XM, Li D, Zhang GM, et al. (2014) Passive transfer of tumourderived MDSCs inhibits asthma-related airway inflammation. Scand J Immunol 79: 98-104. [Crossref]

28. He Y, Wang B, Jia B, Guan J, Zeng H, et al. (2015) Effects of adoptive transferring different sources of myeloid-derived suppressor cells in mice corneal transplant survival. Transplantation 99: 2102-2108. [Crossref]

29. Koehn BH, Apostolova P, Haverkamp JM, Miller JS, McCullar V, et al. (2015) GVHDassociated, inflammasome-mediated loss of function in adoptively transferred myeloidderived suppressor cells. Blood 126: 1621-1628. [Crossref]

30. Kawai H, Minamiya Y, Takahashi N (2011) Prognostic impact of S100A9 overexpression in non-small cell lung cancer. Tumour Biol 32: 641-646. [Crossref]

31. Feng PH, Lee KY, Chang YL, Chan YF, Kuo LW, et al. (2012) CD14(+)S100A9(+) monocytic myeloid-derived suppressor cells and their clinical relevance in non-smal cell lung cancer. Am J Respir Crit Care Med 186: 1025-1036. [Crossref]

32. Su YJ, Xu F, Yu JP, Yue DS, Ren XB, et al. (2010) Up-regulation of the expression of S100A8 and S100A9 in lung adenocarcinoma and its correlation with inflammation and other clinical features. Chin Med J (Engl) 123: 2215-2220. [Crossref]

33. Mandruzzato S, Solito S, Falisi E, Francescato S, Chiarion-Sileni V, et al. (2009) IL4Ralpha+ myeloid-derived suppressor cell expansion in cancer patients. $J$ Immunol 182: 6562-6568. [Crossref]

34. Poschke I, Mougiakakos D, Hansson J, Masucci GV, Kiessling R (2010) Immature immunosuppressive CD14+HLA-DR-/low cells in melanoma patients are Stat3hi and overexpress CD80, CD83, and DC-sign. Cancer Res 70: 4335-4345. [Crossref]

35. Filipazzi P, Valenti R, Huber V, Pilla L, Canese P, et al. (2007) Identification of a new subset of myeloid suppressor cells in peripheral blood of melanoma patients with modulation by a granulocyte-macrophage colony-stimulation factor-based antitumor vaccine. J Clin Oncol 25: 2546-2553. [Crossref]

36. Gabrilovich DI, Nagaraj S (2009) Myeloid-derived-suppressor cells as regulators of the immune system. Nat Rev Immunol 9: 162-174. [Crossref]

37. Ortiz ML, Lu L, Ramachandran I, Gabrilovich DI (2014) Myeloid-derived suppressor cells in the development of lung cancer. Cancer Immunol Res 2: 50-58. [Crossref]

38. Cuervo H, Guerrero NA, Carbajosa S, Beschin A, De Baetselier P, et al. (2011) Myeloidderived suppressor cells infiltrate the heart in acute Trypanosoma cruzi infection. $J$ Immunol. 187: 2656-2665. [Crossref]

39. Cerutti PA (1985) Prooxidant states and tumor promotion. Science 227: 375-381. [Crossref]

40. Raber PL, Thevenot P, Sierra R, Wyczechowska D, Halle D, et al. (2014) Subpopulations of myeloid-derived suppressor cells impair $\mathrm{T}$ cell responses through independent nitric oxide-related pathways. Int J Cancer 134: 2853-2864. [Crossref]

41. Rabe KF, Hurd S, Anzueto A, Barnes PJ, Buist SA, et al. (2007) Global strategy for the diagnosis, management, and prevention of chronic obstructive pulmonary disease: GOLD executive summary. Am J Respir Crit Care Med 176: 532-555. [Crossref]

42. http://www.abs.gov.au/ausstats/abs@.nsf/Lookup/by\%20 Subject/4338.0 201113 Main\%20Features Tobacco\%20smoking 10008. 
43. McCormick MM, Rahimi F, Bobryshev YV, Gaus K, Zreiqat H, et al. (2005) S100A8 and S100A9 in human arterial wall. Implications for atherogenesis. J Biol Chem 280 : 41521-41529. [Crossref]

44. Goyette J, Yan WX, Yamen E, Chung YM, Lim SY, et al. (2009) Pleiotropic roles of $\mathrm{S} 100 \mathrm{~A} 12$ in coronary atherosclerotic plaque formation and rupture. $J$ Immunol 183 : 593-603. [Crossref]

45. Yang Z, Tao T, Raftery MJ, Youssef P, Di Girolamo N, et al. (2001) Proinflammatory properties of the human S100 protein S100A12. J Leukoc Biol 69: 986-994. [Crossref]

46. Iismaa SE, Hu S, Kocher M, Lackmann M, Harrison CA, et al. (1994) Recombinant and cellular expression of the murine chemotactic protein, CP- 10. DNA Cell Biol 13 183-192. [Crossref]

47. Ahmadzai H, Huang S, Hettiarachchi R, Lin JL, Thomas PS, et al. (2013) Exhaled breath condensate: a comprehensive update. Clin Chem Lab Med 51: 1-19. [Crossref]

48. Misko TP, Schilling RJ, Salvemini D, Moore WM, Currie MG (1993) A fluorometric assay for the measurement of nitrite in biological samples. Anal Biochem 214: 11-16. [Crossref]

49. Edgeworth J, Gorman M, Bennett R, Freemont P, Hogg N (1991) Identification of $\mathrm{p} 8,14$ as a highly abundant heterodimeric calcium binding protein complex of myeloid cells. J Biol Chem 266: 7706-7713. [Crossref]

50. Robinson MJ, Hogg N (2000) A comparison of human S100A12 with MRP-14 (S100A9). Biochem Biophys Res Commun 275: 865-870. [Crossref]

51. Ravasi T, Hsu K, Goyette J, Schroder K, Yang Z, et al. (2004) Probing the S100 protein family through genomic and functional analysis. Genomics 84: 10-22. [Crossref]

52. Du X, Tang Y, Xu H, Lit L, Walker W, et al. (2006) Genomic profiles for human peripheral blood T cells, B cells, natural killer cells, monocytes, and polymorphonuclear cells: Comparisons to ischemic stroke, migraine, and Tourette syndrome. Genomics 87: 693-703. [ Crossref]

53. Perera C, McNeil HP, Geczy CL (2010) S100 Calgranulins in inflammatory arthritis. Immunol Cell Biol 88: 41-49. [Crossref]

54. Ryckman C, Vandal K, Rouleau P, Talbot M, Tessier PA (2003) Proinflammatory activities of S100: proteins S100A8, S100A9, and S100A8/A9 induce neutrophil chemotaxis and adhesion. J Immunol 170: 3233-3242. [Crossref]

55. Hofmann Bowman MA, Heydemann A, Gawdzik J, Shilling RA, Camoretti-Mercado B (2011) Transgenic expression of human S100A12 induces structural airway abnormalities and limited lung inflammation in a mouse model of allergic inflammation. Clin Exp Allergy 41: 878-889. [Crossref]

56. Peranzoni E, Zilio S, Marigo I, Dolcetti L, Zanovello P, et al. (2010) Myeloid-derived suppressor cell heterogeneity and subset definition. Curr Opin Immunol 22: 238-244. [Crossref]
57. Filipazzi P, Huber V, Rivoltini L (2011) Phenotype, function and clinical implications of myeloid-derived suppressor cells in cancer patients. Cancer Immunol Immunother 61: 255-263. [Crossref]

58. Huang A, Zhang B, Wang B, Zhang F, Fan KX, et al. (2013) Increased CD14+HLADR-/low myeloid-derived suppressor cells correlate with extrathoracic metastasis and poor response to chemotherapy in non-small cell lung cancer patients. Cancer Immunol Immunother 62: 1439-1451. [Crossref]

59. Tan DB, Fernandez S, Price P, Moodley YP (2014) The proportion and function of peripheral myeloid-derived suppressor cells do not correlate with systemic inflammation in chronic obstructive pulmonary disease. Human Immunology 75: 5-9. [Crossref]

60. Noguera A, Busquets X, Sauleda J, Villaverde JM, MacNee W, et al. (1998) Expression of Adhesion Molecules and G Proteins in Circulating Neutrophils in Chronic Obstructive Pulmonary Disease. Am J Respir Crit Care Med 158: 1664-1668. [Crossref]

61. Nadkarni S, Dalli J, Hollywood J, Mason JC, Dasgupta B, et al. (2014) Investigational Analysis Reveals a Potential Role for Neutrophils in Giant-Cell Arteritis Disease Progression. Circ Res 114: 242-248. [Crossref]

62. Beyrau M, Bodkin JV, Nourshargh S (2012) Neutrophil heterogeneity in health and disease: a revitalized avenue in inflammation and immunity. Open Biol 2: 120134. [Crossref]

63. Manitz MP, Horst B, Seeliger S, Strey A, Skryabin BV, et al. (2003) Loss of S100A9 (MRP14) Results in Reduced Interleukin-8-Induced CD11b Surface Expression, a Polarized Microfilament System, and Diminished Responsiveness to Chemoattractants In Vitro. Mol Cell Biol 23: 1034-1043. [Crossref]

64. Hsu K, Passey RJ, Endoh Y, Rahimi F, Youssef P, et al. (2005) Regulation of S100A8 by glucocorticoids. J Immunol 174: 2318-2326. [Crossref]

65. Lee TH, Jang AS, Park JS, Kim TH, Choi YS, et al. (2013) Elevation of S100 calcium binding protein A9 in sputum of neutrophilic inflammation in severe uncontrolled asthma. Ann Allergy Asthma Immunol 111: 268-275. [Crossref]

66. Masri FA, Comhair SA, Koeck T, Xu W, Janocha A, et al. (2005) Abnormalities in nitric oxide and its derivatives in lung cancer. Am J Respir Crit Care Med 172: 597605. [Crossref]

67. Ellis G, Adatia I, Yazdanpanah M, Makela SK (1998) Nitrite and nitrate analyses: a clinical biochemistry perspective. Clin Biochem 31: 195-220. [Crossref]

68. Lundberg JO, Weitzberg E, Gladwin MT (2008) The nitrate-nitrite-nitric oxide pathway in physiology and therapeutics. Nat Rev Drug Discov 7: 156-167. [Crossref]

69. Schneider T, Sevko A, Heussel CP, Umansky L, Beckhove P, et al. (2015) Serum inflammatory factors and circulating immunosuppressive cells are predictive markers for efficacy of radiofrequency ablation in non-small-cell lung cancer. Clin Exp Immunol 180: 467-474. [Crossref]

Copyright: (C2017 Lim MY. This is an open-access article distributed under the terms of the Creative Commons Attribution License, which permits unrestricted use, distribution, and reproduction in any medium, provided the original author and source are credited. 